\title{
咬合と顎関節に関する研究 $\mathrm{V}$
}

咬合挙上装置装着による顆頭位の変化について

\begin{tabular}{|c|c|c|c|}
\hline 清野 晃孝 & 佐藤 & 克彦 & 酒井 \\
\hline 近江谷尚紀 & 田中 & 義博 & 高橋 \\
\hline 篠田 & 登 & 田島 & 篤治 \\
\hline
\end{tabular}

A Dynamical Studies on Occlusion and Temporomandibular Joint $\mathrm{V}$

Shift of Condylar Position Wearing Occlusal Splint Plate

\author{
Akinori Seino, Katsuhiko Satoh, Yasuhiko Sakai, Naoki Omiya, \\ Yoshihiro Tanaka, Kenji Takahashi, Noboru Shinoda and Tokuji Tajima
}

\section{I. 緒 論}

下額運動時における関節部の疼痛，開口障害あるいは 関節雑音などを口腔領域の主症状とするいわゆる咬合病 occlusal disharmony, 額関節症 temporomandibular syndrome が，今日急速に増加している傾向があるとい われている.このような社会状況にあっては,一般臨床家 もこれらの疾病状態改善に関して, 日常臨床上において も積極的な対応を行わなければならないものと考える.

従来, この種の口腔領域における病変は, 咬合および 䫑関節などの不調和が基本的な原因であり，かつ，咀嚼 筋群の疼痛をも発生し, いわゆる口腔生理機能の正常的 な運営を阻害したためといわれてきた.しかしながら， 現在にあってもいずれが最も重大な発症原因であるかを 正確に指摘することはできない.

また, 一方, これらの咬合病, 瀕関節症がいわゆる一 般心理的状態や精神神経病変的な状態までも惹起すると いわれている.

まず, これらの症候群に対する原因の第一に列せられ るのは新たに製作された歯冠修復物, 有床補緅物などに よる咬合および咬構に関する新しい不正刺激群であると

東北歯科大学歯科補緅学第 2 請座（主任：田島篤治教授） Tohoku Dental University, Department of Removable Prosthodontics (Chief : Prof. Tokuji Tajima) 昭和 60 年 7 月 12 日受付
いわれる.

また，これらの刺激が従来の口腔領域における反射作 用と同化して, occlusal equilibrium あるいは mental confusion などに関して阻害を与えない状態であればそ れらに何も新しい疾病的な問題を起こすことはない.

しかし，いずれの場合にあっても咬合の再構成を必要 とするわれわれ歯科補緅学の分野にあっては, 複雑に錯 綜する口腔領域における筋, 神経機構および物理的な咬 合あるいは顎関節の形態的な状態について，完全な状態 での回復はほとんど不可能といってさしつかえない.し たがって，このような立場にあっては，まず初めにわれ われが行う作業は咬合の改善である.

Karolyi 時代における咬合調整1) 引用するまでもな く, 今日, 非常に多数の咬合調整に関する発表がなされ， 積極的に臨床に取り入れられてきている. その結果，天 然歯に対する咬合調整 ${ }^{2 ~ 5)}$ も同時に加速度的に取り入れ られていることも事実である.

さらに一方においては，いわゆる咬合挙上床と呼ばれ る splint plate が上下顎間に装着され，これにより頡関 節における stress を低下せしめ T.M.J. syndrome から の脱脚をはかる方法が多用されている.これにより、一 時的に顎関節症の症状低下がみられることは事実ではあ るが, これらの方法が長期間にわたって, 有効安全であ るという保障はなく，むしろ splint plate method は天 然歯列の可動性から考えてあくまでも短時間的 stress 除去装置といわねばならない. 
このような意味において，咬合 splint の装着期間の 長短は臨床上すこぶる重要な問題と考える.

Ramfjord とAsh はその著書の中ですでに咬合不全や， 顎関節症が神経症の併発をうながしていることを指摘し ている. また桂と内田6) は，これらの菌科関する心身 症候群があるとし，これらの分析ならびに治療について 述へ，日常歯科臨床での心身医学的アプローチを披瀝す ると同時に，いわゆる心身症には syndrome shift とい う現症があり医師群はそれらの真因を探り歯科医師にあ ってもこれらに対する適切な処置を行わなければならな いと警告している.

しかしながら, occlusal disharmony あるいは, T.M.J. syndrome に関する最も重要な情報源は intercuspidated position を中心とする T.M.J. の状態にあるとわ れわれは考えている.

そこですでに臨床的にすこぶる簡便に利用できる断層 X線写真装置 Sectograph を利用して, 各種咬合条件に おける顆頭位, 開口位における顆頭の挙動, full mouth reconstruction 術前術後における顆頭の比較あるいは, 多量の咬合挙上をともなら症例に関する T.M.J. の状態 変化について詳細な報告を行ってきた。

そこで今回は, Sectograph による断層撮影と同時に computer operated superposition method による顆頭 の挙動調查方法をも加えて, 䫟関節症治療および咬合再 構成の準備段階で使用される咬合挙上方法に関して，20 歳代男女 10 名の被験者について咬合举上装置装着時に おける顆頭の挙動を調査したので，それらの結果につい て報告する。

\section{II. 研究方法}

\section{1. 被験者について}

咬合状態および歯周組織が正常であり，第 3 大臼歯以
外の欠如を認めず充塓物は小窩裂溝部に止まる 20 歳代 の男女 10 名を被験者とした. また，臨床的な診查におい ては咀箖筋群あるいは䫟関節の異常は認められない. 被 験側は各被験者の左右 20 側である.

\section{2. 咬合挙上装置の製作について}

1）上下顎歯列を rubber impression material によっ て印象を行い，超硬石亮によって作業用模型を製作した. また, transfer bow と maxillomandibular record とに よって parallel shift ができるように改造した arcon type ball and slot articulator Denar Track II $に$ mounting を行った. transfer の顆頭の位置については, あら かじめ metal grid を被験者の両側煩面に貼付し, 左右 の cephalogram 上において一応の臨床的な位置の確認 を行った（図 1，2).

2）矢状顆路傾斜を $90^{\circ}$ に固定し, protrusive-retrusive 調節機構により condylar sphere を強制的に下方へ $3 \mathrm{~mm}$ 移動せしめた. この状態における上下顎臼歯部咬 合面間に acrylic resin を用いた splint plate を製作し， 口蓋床で連結した．なお，実際に使用される咬合挙上装 置とはやや異なり, vertical stop の付与後側方運動に対 する調整は行わず，咬合面の被覆は上䫅㛲側咬頭頂でと どめた maxillo stabilization variation type である (図 3〜5).

\section{3. 撮影顎位について}

Sectograph による規格断層 X 線写真撮影顎位は, i.p. : 咬頭嵌合位および o.s.p. : 咬合挙上装置装着時で ある(図6)。

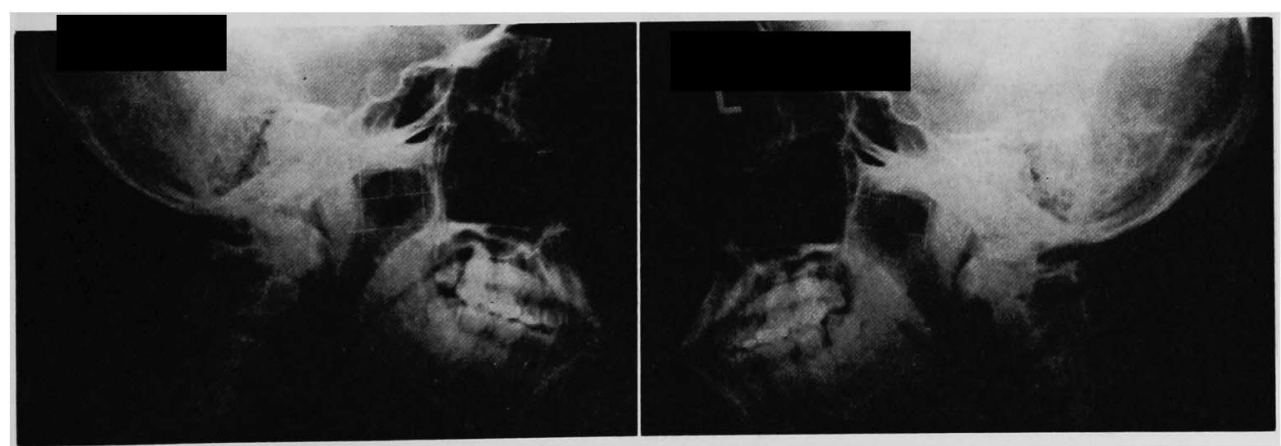

图 1 被験者の规面に金属 grid を貼付した状態の cephalogram 


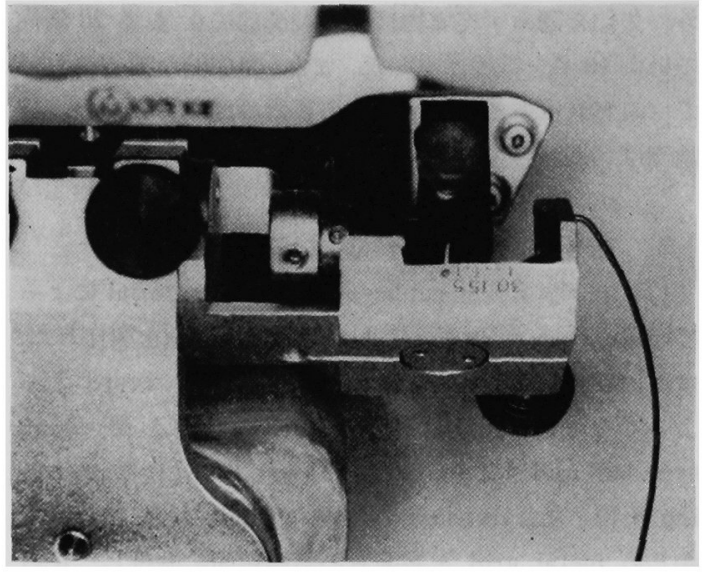

図 2 parallel shift ができるように改造した Denar Track II 咬合器

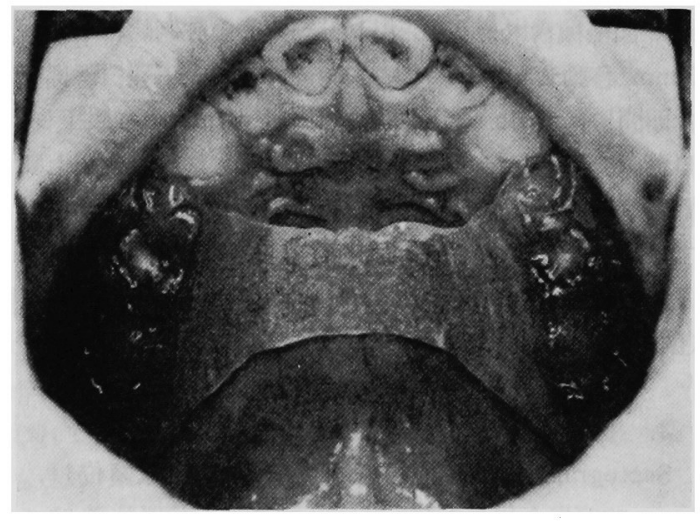

図 4 上顎に装着した咬合挙上装置

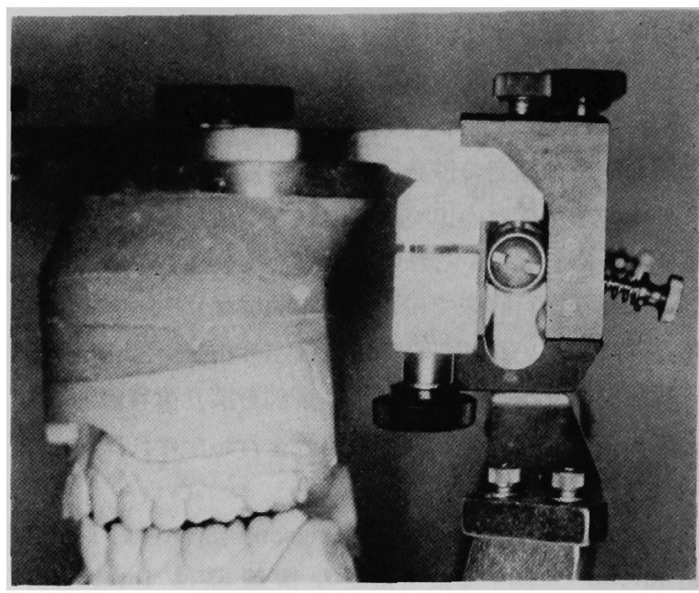

图 3 矢状顆路傾斜を $90^{\circ}$ に固定し protrusive-retrusive 調節機構により condylar sphere 老強制的に下方 へ $3 \mathrm{~mm}$ 移動させた状態

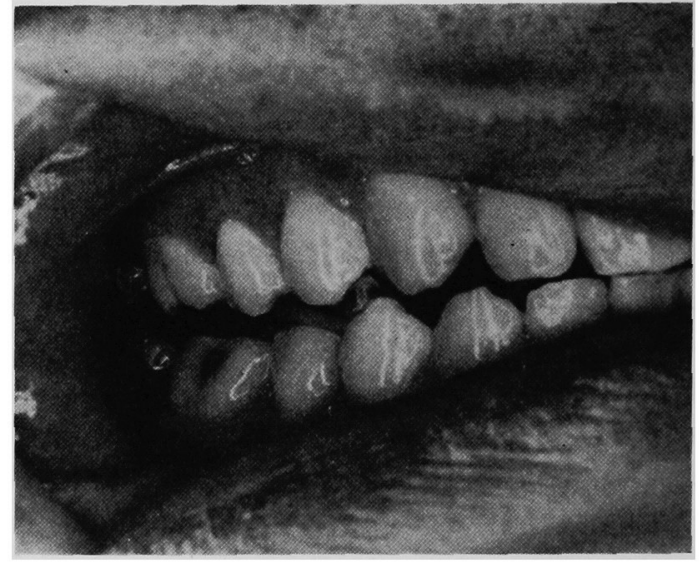

図 5 咬合举上装置装着時の嫰合状態

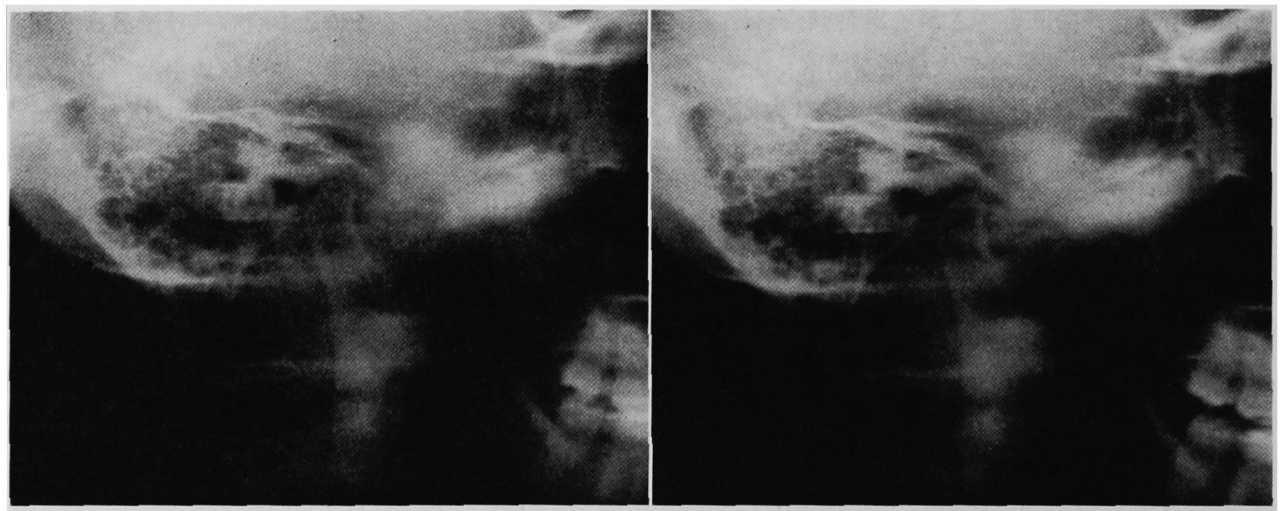

図 6 sectogram

左：咬頭嵌合位

右：咬合挙上装置装着時 
4. Sectograph による T.M.J. の断層撮影と computer operated superposition method による 顆頭の挙動調査方法について

頭部規格断層X線撮影装置として，米国 Quint 社製 Sectograph を使用し, 顆頭中央を通りフィルム方向 15 度回転させた断面を対象として撮影を行った。

断層撮影面の決定法にあたっては, 今回の測定対象と した被験者 10 名について，あらかじめ頭部規格X線写 真法により撮影した前頭面像によって顆頭間距離の測定 を行うと同時に, 解剖的計測基準に準じた顆頭中央部指 定法すなわち㛲部表面計測による煩骨弓幅の $1 / 2$ より
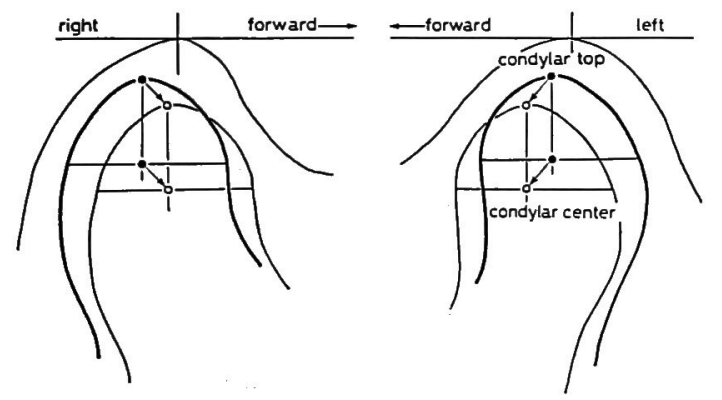

図 7 咬合挙上装置装着による顆頭頂と顆頭中心の変位解説
$18 \mathrm{~mm}$ を減じた值を参考とした. 撮影条件は, 焦点 $1.0 \times$ $1.0 \mathrm{~mm}^{2}$, 焦点フィルム間距離 $1,650 \mathrm{~mm}$ ，フィルム断層 面間距離は平均 $80 \mathrm{~mm}$, 管電圧 $76 \mathrm{kVp}$, 管電流 $100 \mathrm{~mA}$, フィルムはさくら $\mathrm{AL}$ タイプ, 増感紙は東芝 $\mathrm{RM}$, 有効 管球移動角度は 15 度である. 頭部の固定にあたっては, 撮影側をフィルム面に対面するように被験者を撮影用椅 子に通常の座位の姿勢で固定し, 両側外耳道に ear rod を挿入した。 なお前後的あおりの固定は眼点に接触する 固定装置を用いた. また，各条件における sectogramに ついては 10 倍大のトレーシングを行い計測原図とした. intercuspidated position および occlusal splint position における T.M.J. の形態を digitizer 上において, トレースにより PC $9801 \mathrm{E}$ および PC $9881 \mathrm{~K}$ により記 録させ, computer graphic による computer operated superposition methodによって顆頭の移動後の位置, 方 向、および距離を算出すると同時に computer graph 上 に自動作図させた. 標点は顆頭頂点および顆頭頂点直下 $5 \mathrm{~mm}$ の仮顆頭中心を設定して計測上の標点とした. 作 図時の print は NEC miniace graphtic 使用し “ computer operated superposition method " の完成をみた (図 7 ).

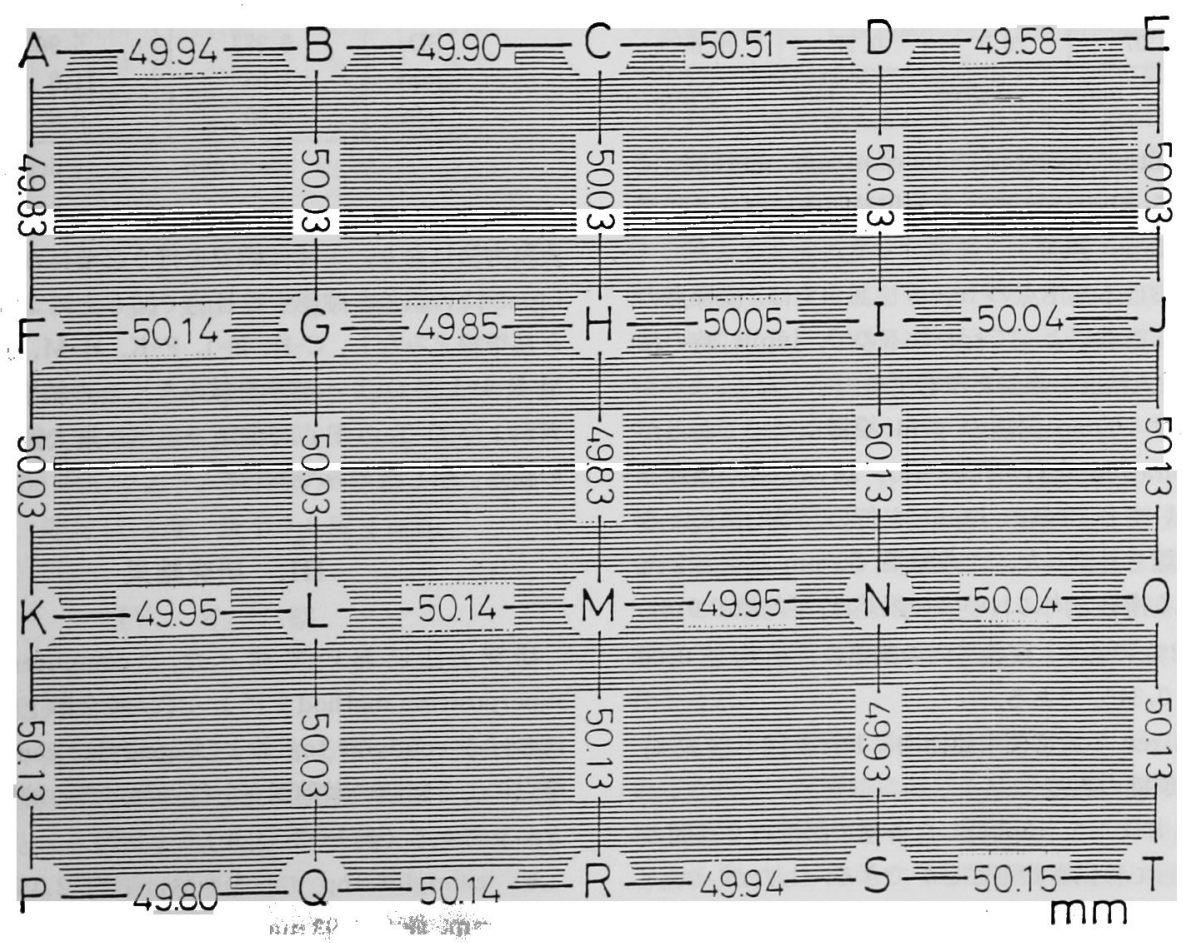

图 8 digitizer-computer process 上に㧍ける測定精度 
$190-1420$

補緅誌

表 1 咬合举上装膡装着による顆頭頂と顆頭中心の変位

\begin{tabular}{|c|c|c|c|c|}
\hline & \multicolumn{2}{|c|}{ shift of condylar top } & \multicolumn{2}{|c|}{ shift of condylar center } \\
\hline & distance & inclination & distance & inclination \\
\hline ar & 2.04 & 34.0 & 1.92 & 42.3 \\
\hline al & 2.93 & 53.6 & 2.94 & 49.8 \\
\hline $\mathrm{br}$ & 1.81 & 36.9 & 1.81 & 35.4 \\
\hline bl & 2.01 & 29.9 & 1.71 & 38.3 \\
\hline $\mathrm{cr}$ & 2.42 & 57.2 & $2.26^{\prime}$ & 62.1 \\
\hline $\mathrm{cl}$ & 2.21 & 41.3 & 2.26 & 38.0 \\
\hline $\mathrm{dr}$ & 1.82 & 55.5 & 1.74 & 56.5 \\
\hline $\mathrm{dl}$ & 3.15 & 40.4 & 3.17 & 39.6 \\
\hline er & 1.82 & 55.5 & 1.75 & 53.1 \\
\hline el & 2.28 & 48.2 & 2.31 & 49.7 \\
\hline $\mathrm{fr}$ & 2.35 & 67.8 & 2.34 & 66.8 \\
\hline $\mathrm{fl}$ & 1.09 & 36.5 & 1.01 & 33.7 \\
\hline $\mathrm{gr}$ & 2.36 & 35.8 & 2.41 & 34.9 \\
\hline $\mathrm{gl}$ & 1.21 & 40.7 & 1.15 & 44.3 \\
\hline $\mathrm{hr}$ & 1.07 & 20.3 & 0.77 & 29.6 \\
\hline hl & 1.28 & 66.0 & 1.42 & 54.2 \\
\hline ir & 3.88 & 41.2 & 3.71 & 43.4 \\
\hline il & 1.51 & 46.9 & 1.61 & 39.4 \\
\hline jr & 3.93 & 48.7 & 4.98 & 37.2 \\
\hline jl & 1.88 & 53.0 & 1.96 & 46.4 \\
\hline M & 2.153 & 45.47 & 2.162 & 44.74 \\
\hline SD & 0.818 & 12.01 & 0.974 & 9.95 \\
\hline $\max$ & 3.93 & 67.8 & 4.98 & 66.8 \\
\hline $\min$ & 1.07 & 20.3 & 0.77 & 29.6 \\
\hline
\end{tabular}

1) computer operated superposition method に おける digitizer の通常使用範囲内における基準 点の input 誤差

本研究における基準点の input にあっては, 座標点の 通常表示は 6 析数によって行われるので, input 時の検 者の data 投入精度が誤差を左右する因子となる.

図 8 に示す $50 \mathrm{~mm}$ 間隔の grid 模様についてあらか じめ caliburation を行ったのちに, 20 点の各座標点そ れぞれについて各 10 個の input を行い, 平均值による 座標点間距離を計測した.この結果, $50 \mathrm{~mm}$ 基準とした 場合における横軸方向においての誤差は, 平均値 $0.01 \%$, 最大值 $1.02 \%$ であり, 縦軸方向の誤差は, 平均值 0.06 $\%$ ，最大値 $0.34 \%$ である.

2) digitizer の通常使用範囲内における図形移動 時 の基準線の誤差

digitizer によって input した各種の図形は 2 点間の 基準線によって移動させることができる.したがって， 基準点の input point の精度が図形の移動精度と同義語 となるので,この問題に関しては前項とまったく同種の
29 巻 6 号 (1985)

\begin{tabular}{|c|c|c|}
\hline & \multicolumn{2}{|c|}{$\begin{array}{l}\text { difference value between } \\
\text { condylar top and condylar center }\end{array}$} \\
\hline & distance & inclination \\
\hline ar & -0.12 & 8.3 \\
\hline al & 0.01 & -3.8 \\
\hline $\mathrm{br}$ & 0.00 & -1.5 \\
\hline bl & -0.30 & 8.4 \\
\hline $\mathrm{cr}$ & -0.16 & 4.9 \\
\hline $\mathrm{cl}$ & 0.05 & -3.3 \\
\hline $\mathrm{dr}$ & -0.08 & 1.0 \\
\hline $\mathrm{dl}$ & 0.02 & -0.8 \\
\hline er & -0.07 & -2.4 \\
\hline el & 0.03 & 1.5 \\
\hline $\mathrm{fr}$ & -0.01 & -1.0 \\
\hline $\mathrm{fl}$ & -0.08 & -2.8 \\
\hline gr & 0.05 & -0.9 \\
\hline $\mathrm{gl}$ & -0.06 & 3.6 \\
\hline $\mathrm{hr}$ & -0.30 & 9.3 \\
\hline $\mathrm{hl}$ & 0.14 & -11.8 \\
\hline ir & -0.17 & 2.2 \\
\hline il & 0.10 & -7.5 \\
\hline $\mathrm{jr}$ & 1.05 & -11.5 \\
\hline $\mathrm{jl}$ & 0.08 & -6.6 \\
\hline $\mathrm{M}$ & 0.009 & -0.74 \\
\hline SD & 0.273 & 5.96 \\
\hline $\max$. & 1.05 & 11.8 \\
\hline $\min$ & 0.00 & 0.8 \\
\hline
\end{tabular}

実証方法になり，とくに調查を行う必要はないが， 2 点 input 時の誤差を確認する目的で図 8 上における $\mathrm{A}-\mathrm{F}$ を基準線とみなし， C-H， E-J, F-K, H-M, J-O, K-P， $\mathrm{M}-\mathrm{R}$ および O-T 八移動を試みた. この結果, J-O の 0 点および O-T の $\mathrm{T}$ 点で前項で述べた最大值以内の少量 の誤差を示したのみであった.

\section{III. 研究結果}

研究方法において述べた, “ computer operated superposition method”によって，咬合挙上装置装着時 における condylar top および condylar center の 2 基 準点による顆頭の挙動調査を行った. その結果はつぎの とおりである(表 1〜3, 図 9).

1. condylar top の移動距離は平均 $2.153 \mathrm{~mm}, \mathrm{SD}$ $0.818 \mathrm{~mm}$, 最大 $3.93 \mathrm{~mm}$, 最小 $1.07 \mathrm{~mm}$ である.

2. F-H plane を基準とした移動角度は前下方へ平均 
表 3 F-H 平面と咬合平面との開角度 inclination of occlusal plane

\begin{tabular}{|c|c|c|c|c|}
\hline & \multicolumn{2}{|c|}{ right side } & \multicolumn{2}{|c|}{ left side } \\
\hline & \multicolumn{2}{|c|}{ cephalogram } & \multicolumn{2}{|c|}{ cephalogram } \\
\hline base line & ear rod & audi. can. & ear rod & audi. can. \\
\hline ar & 10.1 & 8.0 & & \\
\hline al & & & 12.6 & 11.5 \\
\hline $\mathrm{br}$ & 13.0 & 8.8 & & \\
\hline bl & & & 9.0 & 6.9 \\
\hline $\mathrm{cr}$ & 20.2 & 16.4 & & \\
\hline $\mathrm{cl}$ & & & 19.0 & 19.5 \\
\hline $\mathrm{dr}$ & 10.5 & 11.3 & & \\
\hline $\mathrm{dl}$ & & & 9.8 & 11.5 \\
\hline er & 15.0 & 12.5 & & \\
\hline el & & & 13.3 & 13.5 \\
\hline fr & 13.2 & 13.5 & & \\
\hline $\mathrm{fl}$ & & & 13.7 & 9.0 \\
\hline gr & 19.8 & 12.2 & & \\
\hline gl & & & 23.0 & 17.5 \\
\hline $\mathrm{hr}$ & 12.2 & 11.0 & & \\
\hline $\mathrm{hl}$ & & & 8.3 & 8.8 \\
\hline ir & 14.0 & 8.1 & & \\
\hline il & & & 7.0 & 7.8 \\
\hline jr & 9.4 & 8.2 & & \\
\hline $\mathrm{j} 1$ & & & 7.3 & 6.7 \\
\hline M & 13.74 & 11.00 & 12.30 & 11.27 \\
\hline $\mathrm{SD}$ & 3.74 & 2.77 & 5.26 & 4.41 \\
\hline $\max$ & 20.2 & 16.4 & 23.0 & 19.5 \\
\hline $\min$. & 9.4 & 8.0 & 7.0 & 6.7 \\
\hline $\mathrm{SD} / \mathrm{M}$ & 27.22 & 25.18 & 42.76 & 39.13 \\
\hline
\end{tabular}

45.47 度, $\mathrm{SD} 12.01$ 度, 最大 67.8 度, 最小 20.3 度であ 3.

3. condylar top と condylar center との差は移動距 離において平均 $0.009 \mathrm{~mm}, \mathrm{SD} 0.273 \mathrm{~mm}$, 最大 1.05 $\mathrm{mm}$ 最小 $0.00 \mathrm{~mm}$ であり, 角度差は平均 -0.74 度, SD 5.96 度, 最大 11.8 度, 最小 0.8 度である.

\section{IV. 考察}

\section{1. 研究目的について}

一般に，下嚬の前方要素といわれる咬合面，咬合状態 および上下顎の咬合面関係と後方要素と呼ばれている顎 関節の状態とくに顆路とは，伝統的考え方，gnathology 的考え方あるいは生理的考え方とをとわず同一固体視し てきたように思われる. その第 1 の理由は顆路記録必要 性の定着化であり，第 2 は咬合面と顆路の協調性を目的
とした咬合器使用要求である.とくに近年, 半調節性咬合 器, 全調節性咬合器と呼ばれるように作業側の微細な運 動までも記録することが必要であるとする gnathology 的方向一進んできたようである.

このように臨床的にも顆路と咬合面との関与を非常に 重要視し, 前方の咬合面と後方の顆路は同一固体とし て, 臨床上の手段や手順が考案, 実用化されてきた. む ちろんわれわれの臨床技法もこれらの考え方の線上にお いて日常臨床を消化してきたことであり，今後も格段な る変動や劇的な変化が生じる可能性は臨床上きわめてう すい. しかしながら，われわれの研究結果は，咬合面の 行動と顆頭の行動とが同一固体あるいは㓮体性を有して いないことを示している.

前報》ににおいて咬合面による強制が，顆頭位におよぼ すか否かについて実験的検討を行い顆頭の前下方への移 動は比較的容易に企てることができるが他の方向への可 動，可変位は困難であることを報告した．すなわち，咬 合面による強制効果は顆頭のすべてを支配できないこと である.

論をまつまでもなく，下顎運動と顆頭の挙動に関し て, 主要概念を確立しこの分野における研究の推進に大 きな影響を与えた石原ら ${ }^{8,9)}$ は下顎運動に対する頢 関 節 の意義の項で，下顎運動に対して関節が重要な役割を示 すことには疑点はないが重要視する程度に問題があると しており，この考え方の差によっては gnathology のよ らな機械的, 幾何学的な正確性を咬合面と顆頭に要求す る立場むあれば，また一方，顎関節には自由度があると する見方も非常に多いと指摘している．また，顎関節部 がある程度の自由度をもっていることは当然考えられる が，いかなる自由度かについては不明の簌囲もあり，顆 頭がある特定の運動範囲内ではきわめて自由円滑に動く ことは明らかでもあるとの見方も成り立つとしている. まさにわれわれは, この分野を重要な研究の一つに擬し て, 顆頭の挙動に焦点をあて, 基本的な 調 查 ${ }^{10 \sim 12)}$ 队咬 合再構成をともなう臨床例における顆頭の 動き ${ }^{13 \sim 15)}$ に ついても報告を行い，多角度からの検索を進めてきたが 顆頭の自由度については, 判然とする結果はみいだしえ なかった.

そのような意味において, 顆頭の自由度のみに焦点を あてた咬合力発現時における顆頭の移動に関する研究11 はその第 1 段階であった. 顆頭は上下的自由度を有する とする見方をふまえて，頭部規格断層X線撮影装置 Sectograph を用いて， 20 歳代正常咬合者 10 名の左右 20 側 を対象とし咬合力発現時における顆頭の移動について検 

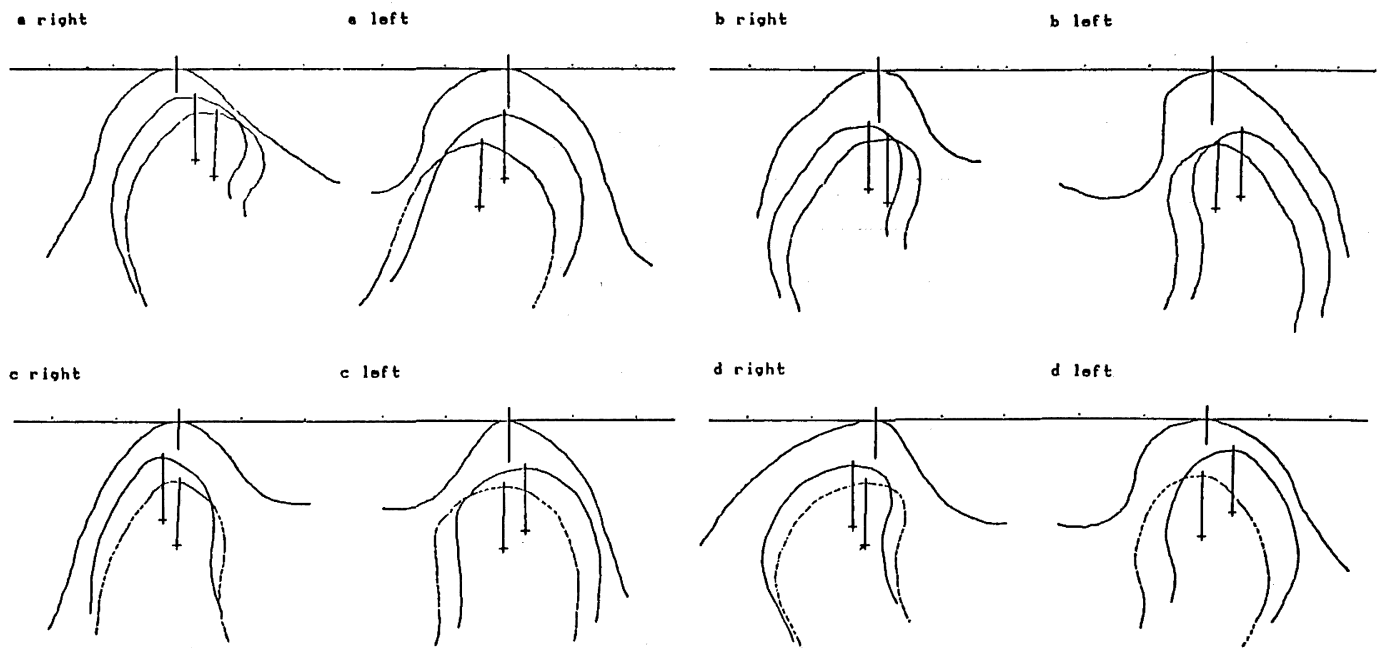

c lof $t$

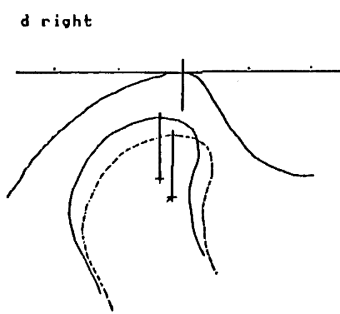

d loft
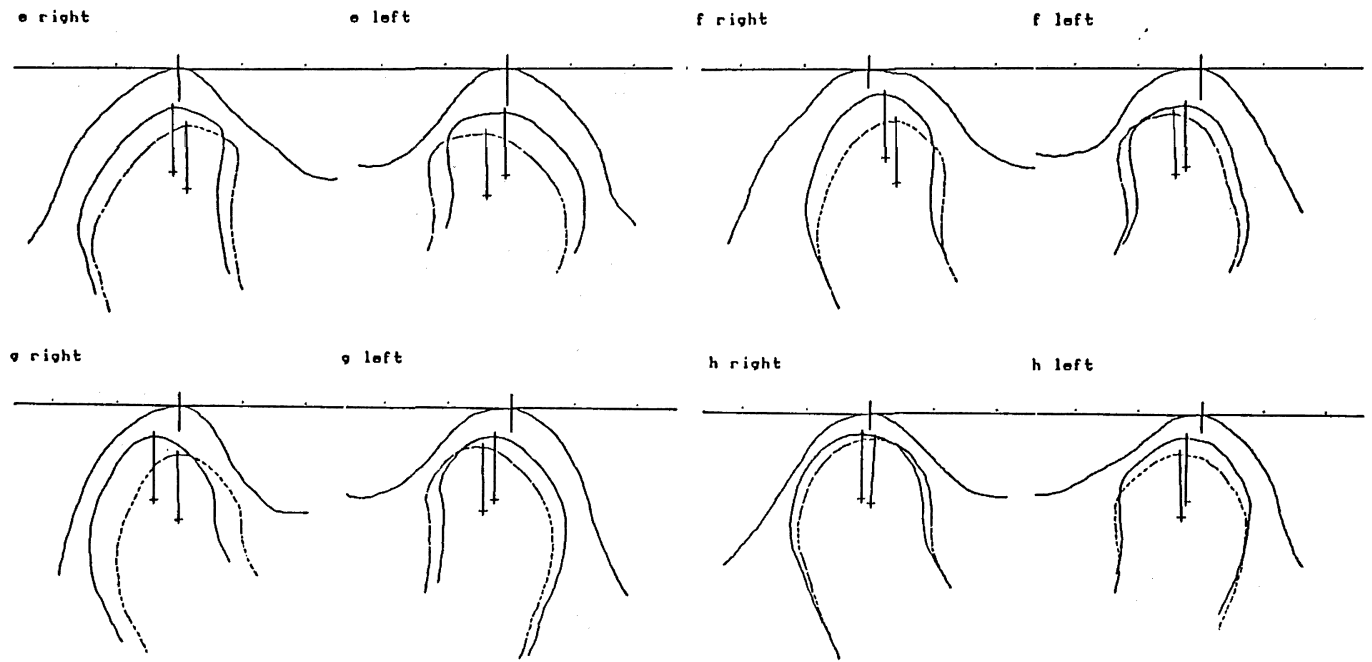

Q lof $t$
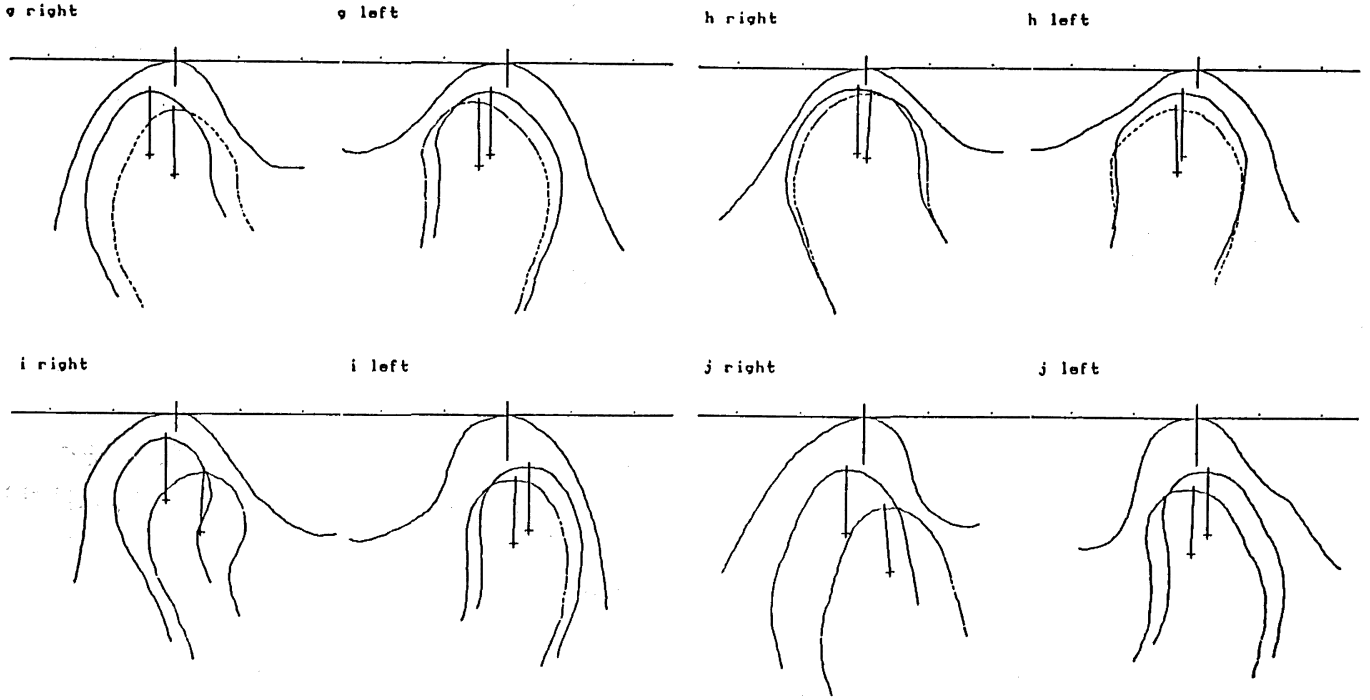

図 9 “ computer operated superposition method”による咬頭嵌合位と咬合挙上装置装着時の顆頭位の変位図

索を行った. その結果, 咬頭嵌合位に㧍ける咬みしめに よる各被験者の右側における顆頭頂の運動方向は, 後上 方へ移動するもの 4 例, ほほ上方へは 3 例, 後方へは 2
例, 後下方へは 1 例であり, 左側では, 後上方, 上方へ は各々 3 例, 後方へは 2 例, 後下方へは 1 例であり, 移 動のみられないものが 1 例みられ, 移動距離は, 最大 
$1.91 \mathrm{~mm}$, 最小 $0.00 \mathrm{~mm}$, 平均 $0.710 \mathrm{~mm}, \mathrm{SD} 0.493 \mathrm{~mm}$ であった. また，かみしめにより，顆頭が関節感前壁よ り遠ざかる方向へ移動しているもの 15 例, 近うくもの が 5 例みられたと報告した. 上下矤咬合面関係を一定と しても，咬合力を発現することによって，顆頭頂はわず かながらも各方向一移動を示した. しかし，これらの移 動量は平均値および SD からみれば，一般的にいう自由 度があるという表現からすればいかにも小さい值にすぎ ない感がある.

そこで前報つににおいて，強制御咬合装直による顆頭の 強制的移動の可能性について調査を行った. すなわち, full mouth reconstruction を要求する被験者において, 残存歯群支台歯形成時を利用し，基準位を咬合再構成後 の咬頭嵌合位に置き，咬合器上において顆頭を $30^{\circ}$ 前下 方直下方および $30^{\circ}$ 後下方へ $3 \mathrm{~mm}$ ずつ移動せしめる目 的で製作した強制御咬合装置を，口腔内上下顎咬合面間 に介在せしめたときの生体における顆頭の可動, 可変位 性について検討を行ったが，すへてての場合において移動 距離の短縮がみられ，また，左側にあってはいずれの強 制位においても顆頭が前下方に移動し，加えて，後下方 強制位, 直下方強制位, 前下方強制位の順に移動量なら びに前方成分比率の増加が認められ，右側における前下 方強制位は顆頭が前下方に移動し, 移動距離が最も大き く下方強制位は前下方に移動するが, 前方移動量に比し て下方移動量が極端に少なく, 後下方強制位は僅少なる 前方移動をともなう下方移動を示し，移動距離が極端に 小さい，また, desirable place に近似した位置を示した ものは前下方強制位のみであり, 直下方強制位, 後下方 強制位はともに desirable direction とほど遠い移動性 を示し，とくに前下方への移動は容易であるが，後下方 変位に対しては resistibilityを有しているとの結果を得 た.これらの内容をふまえて今回の研究, 調查を行った ものである.

\section{2. 研究結果について}

結果の項における図 9 および表 1 に示されるように, 咬合挙上装置によって構成した desirable direction で ある直下方向的変位を示したものは 1 例もなく，いずれ の場合も挙上後の顆頭は前下方人向かう傾向にあり, ほ ほ $45^{\circ}$ 前後に集中している. また, F.H.L. と O.P. 開角 度の影響もほとんど認められない（表 3 ）。

左右側総合的にみた場合にあっては, 顆頭頂の移動距

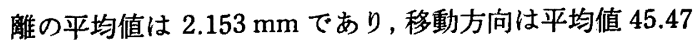
度を示し, SD 範囲も比較的せまくとくに方向性に関す
る結果は, 数量的安定さえ認められると考えている一 方, 仮顆頭中心の移動距離の平均値は $2.162 \mathrm{~mm}$ であ り, 移動方向は平均値 44.74 度を示した. このように顆 頭頂および仮顆頭中心とにおける挙動の差はすこぶる少 なく，今回のような下效移動をきたす咬合挙上装置にあ っては, 両者を比較検討する意義をみいだすことはでき なかった（表 2 ).

さて, occlusal splint, bite plate, bite plane あるいは night guard などと呼称される咬合挙上板あるいは咬合 挙上装置の目的は, われわれの立場からは bruxisum と occlusal disharmony に対する短期的処置に集約される. もちろん, この他にも矯正的咬合改善方法として, 比較 的長期間使用される場合もあるが, 今回，われわれの意 とするところは前者である. したがって，保母も指摘す るように Sears ${ }^{17)}$, Posselt ${ }^{18)}$, Stuart ${ }^{19)}$, 小林ら ${ }^{20)}$ が提唱 する occlusal pivod あるいは咬合挙上にともなう temporomandibular joint $の$ stress 解消装置は, 装置装着後 短時間内にその効果が認められるので， 2 週間以内の使 用が限度であり長期間使用によって生じる咬合状態の変 化は, 歯科短正学のいう咬合挙上装置と同様, 咬合接触 せしめた部位以外の歯の挺出をうながす結果となる. し たがって, 臨床上の咬合挙上装置装着時間は, 歯列や下 顎骨などの矯正的変形を期待する経過時間とはまったく 異なるべきものであり, われわれの研究における咬合挙 上装置装着後の調査時までの経過時間が，いずれも2〜 3 時間内であることが，研究目的からみて短期に過ぎる とは考えられない. したがって装置装着後の調査時にお ける経過時間の影響は無視しうるものと考える.

さて，われわれの研究結果から，前述のごとく，いず れの場合もほほ $45^{\circ}$ 前下方へ condyle が移動する実 証事実から（表 1，図9），先人らの教示する occlusal splint などによる condyle の移動方向はいささか修正 せざるをえない，もちろん，前下方も広い意味で下方と 呼ぶのであれば表現の違いかとも思われるが（図 10）。

関節䆟中の顆頭が，少量の幅を持つ一定の顆路を描い て自由に前後的に動くか, または，回転しながら顆路の 上を tracking することは可能である. 石原らが指摘す る自由度とはこの意味と推察される. 顆頭は最大開口時 関節前方結節から逸脱する動きをとるが，そのような特 殊な条件下にあっても常に ligamentに牽引されており， 通常の健全な状態にあっては ligament の弛緩はありえ ないので顆頭は強い制約を受けていると思われる.すな わち, 本研究の結果において顆頭の挙動が desirable direction に合致せず, desirable placement が不可能で 
$194-1424$

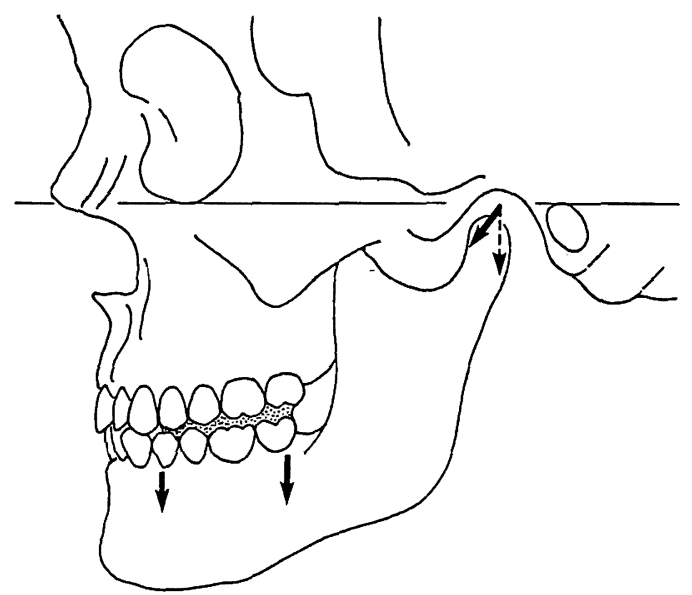

図 10 bite-guard-like plates $や$ temporary splint $の$ pivotによって condyle は下方へ移動するという

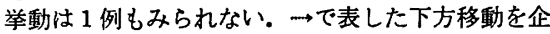
った場合でも全例においていで表した前下方への移 動を示した

あったことは健全な若年者群にあっては，顆頭の運動方 向性に関しての自由度は著しく制約を受けているものと 思われる. すなわち, occlusal splint の装着による temporomandibular joint の stress の解消は, 顆頭の前下方 への移動によるものであり，Possel ${ }^{18)}$ の画く図に示さ れたやや後方移動のある下方ではない.したがって, occlusal pivot 方式により臼歯部に rotation center もうけて，下䫟歯列に回転を起こさせるという方法にも 顆頭の移動方向に関して疑いがもたれる. しかし, 高年 齢化するにつれて ligament が驰緩するのは否定しがた く, condylar path が serious さを失うと顆路の幅が広 がり行動範囲にゆとりが生じてくる. そのような高齡化 的変化によって, 下方への自由度が徐々に発現する可能 性は高まると思われる。 しかし, 大石による新鮮屍体に おける自由度に関する検索結果から, 顆頭位には若干の 自由度があると思われるが，その幅はかなり狭くほとん ど一定值といってよいとする結果と, 今回の若年者群の 顆頭の挙動とは同意義とわれわれは考えている.

さて，咬合条件が顆頭の挙動を完全支配しないとする 今回の報告は, 今後に煩わしい問題を提起したと思う. それは, maltiflush 法あるいはすでにわれわれが大きな 欠点 ${ }^{21)}$ を指摘してはいる pantograph 法などの間接的な 方法で，咬合面関倸あるいは下頡の運動状況から関節内 における顆頭の位置や挙動の計測を高精度で行う研究に あっては, 下顎骨を剛体としてみることを原則としてい る. しかし，われわれの研究結果は同一固体的状態にあ
29 巻 6 号 (1985)

るとは考えられない顆頭の挙動状態を示し， disirable direction 一ほとんど動いていず, しかも，下顎骨上にお いて前後的なたわみ現象が生じたと思われることは下顎 骨が flexibility を有していることを示し，今後のこの 種の研究と臨床に難題をなげかけたものと考える.

\section{V. 結 論}

Sectograph による断層撮影と同時にわれわれが開発 した “ computer operated superposition method" に よる顆頭の挙動調查方法によって, 穎関節症治療あるい は咬合再構成の淮備段階で使用される咬合挙上方法に関 して, 20 歳代男女 10 名の被験者について, 咬合挙上装置 装着時に扔ける顆頭の挙動を調査した. それらの結果は つぎのとおりである.

1. condylar top の移動距離は平均 $2.153 \mathrm{~mm}, \mathrm{SD}$ $0.818 \mathrm{~mm}$, 最大 $3.93 \mathrm{~mm}$, 最小 $1.07 \mathrm{~mm}$ である.

2. F-H plane を基準とした移動角度は前下方へ平均 45.47 度, SD 12.01 度, 最大 67.8 度, 最小 20.3 度であ る.

3. condylar top と condylar center との差は移動距 離において平均 $0.009 \mathrm{~mm}, \mathrm{SD} 0.273 \mathrm{~mm}$, 最大 1.050 $\mathrm{mm}$, 最小 $0.000 \mathrm{~mm}$ であり, 角度差は平均 -0.740 度, SD 5.96 度, 最大 11.8 度, 最小 0.8 度である.

研究の推進にあたって,ご指導を賜った東京歯科大学関根 弘教授に謝意を表すると同時に，ご協力をいただいた本教室元 医局員長谷川光昭先生, 佐々木正博先生および放射線学教室大 坊元二技師に深響する.

\section{文献}

1) Ramfjord and Ash: OCCLUSION, 243 245, W.B. Saunders Company.

2) Jankelson, B. : A technique for obtaining optimum functional relationship for the natural dentition. Dent. Clin. North America, $17: 131 \sim 141,1960$.

3) Ramfjord, S.P. : Dysfunctional temporomandibular joint and muscle pain. J. Prosth. Dent., $26: 353 \sim$ 374, 1961.

4) Schuyler, C.H.: Fundamental principles in the correction of occlusal disharmony, natural and artificial. J. Am. Dent. A., $31: 1193 \sim 1202,1935$.

5) Shore, N.A. : Equilibration of the occlusion of natural dentition. J. Am. Dent. A., $33: 414 \sim 427$, 
1952.

6）桂 戴作, 内田安信 : 心身症と歯科治療, 序 $3 \sim 6$, 東 京, デンタルダイヤモンド, 1978.

7）高橋健二, 佐藤克彦, 清野晃孝, 田中義博, 近江谷尚 紀, 酒井靖彦, 早坂正博, 田島篤治 : 咬合と䫑関節に関 する研究 III 顆頭位の強制的移動の可能性について, 補経誌, $29: 1310 \sim 1324,1985$.

8）石原寿郎, 藍 稔 : 咬合に関する見解の種々相, その 1, 下額位について，歯界展望，30:809 819, 1967.

9）石原寿郎, 藍 稔: 咬合に関する見解の種々相, その 2, 下額運動について，齿界展望，31:29 40, 1968.

10）早坂正博, 高橋健二, 片岡保夫, 田島篤治 : Sectograph による顆頭位の研究, 第 1 報 各下顥位における顆頭位 について, 補緅誌, $27: 550 \sim 572,1983$.

11）早坂正博, 高橋健二, 酒井靖彦, 浅野 健, 田中義博, 近江谷尚紀, 片岡保夫, 田島篤治 : Sectograph による 顆頭位の研究，第 2 報 咬合力発現時における顆頭の移 動について, 補綴誌, $27: 573 \sim 584,1983$.

12）早坂正博, 高橋健二, 田中義博, 近江谷尚紀, 酒井靖 彦, 田島篤治 : Sectograph による顆頭位の研究，第 4 報 開口初期における顆頭位について, 補経誌, 27 ： $1167 \sim 1181,1983$.

13）高橋健二, 早坂正博, 酒井靖彦, 近江谷尚紀, 田中義 博, 田島篤治 : 咬合再構成における治験 (I) 多量の咬 合挙上をともなう症例, 東北歯会誌, $11: 20 \sim 36,1984$.
14）酒井靖彦，塩沼直蔵，近江谷尚紀，田中義博，池田光 男, 早坂正博, 高橋健二, 篠田 登, 田島篤治 : 咬合之 䫓関節に関する研究 I 咬合再構成前後にお们顆頭位 について, 補緅誌, $29: 1070 \sim 1094,1985$.

15）清野晃孝, 田中義博, 酒井靖彦, 近江谷尚紀, 早坂正 博, 高橋健二, 片岡保夫, 田島篤治 : 咬合と顎関節に関 する研究II 残存歯 Splint を行った部分欠損例の咬 合再構成前後における顆頭位について, 補緅誌, 29 : $1250 \sim 1262,1985$.

16）保母須弥也：咬合学事典, 東京, 蓄林, 29 30, 1978.

17) Sears, V.H. : Occlusal pivots, J. Prosth. Dent., 6 : $332 \sim 338,1956$.

18) Posselt : Physiology of occlusion and rehabilita. tion, 242 248, 1971.

19) Stuart, C.E. : Principles involved in restoring occlusion to natural teeth, J. Pros. Dent., $10: 304 \sim$ $313,1960$.

20）小林義典, Ash,. M. : オクルーザル・パイトプレー ン・スプリントの設計と生物学的カ学, 歯学, 69 : 583 587, 1981.

21）高橋健二, 早坂正博, 酒井靖彦, 近江谷尚紀, 田中義 博, 清野晃孝, 池田光男, 田島篤治: Sectograph に よる顆頭位の研究, 第 5 報 hinge bow および pantograph のクラッチトレー装着による顆頭の挙動につい て, 補緅誌, $29: 139 \sim 157,1985$. 